\title{
The Readiness of Smokers to Quit Smoking
}

\author{
Septian Emma Dwi Jatmika ${ }^{1}$, Muchsin Maulana ${ }^{1}$, Kuntoro $^{2}$, Santi Martini ${ }^{2} \&$ Beni Setya Anjani ${ }^{1}$ \\ ${ }^{1}$ Public Health Faculty, Universitas Ahmad Dahlan, Indonesia \\ ${ }^{2}$ Public Health Faculty, Universitas Airlangga, Indonesia \\ Correspondence: Septian Emma Dwi Jatmika, M.Kes, Faculty of Public Health, Universitas Ahmad Dahlan, \\ Yogyakarta, Jl. Prof. Dr. Soepomo, S.H., Janturan, Warungboto, Umbulharjo, Yogyakarta 55164, Indonesia. \\ E-mail: septianemma@ikm.uad.ac.id
}

Received: September 24, 2018 Accepted: December 17, 2018 Online Published: December 30, 2018

doi:10.5539/gjhs.v11n1p172 URL: https://doi.org/10.5539/gjhs.v11n1p172

\begin{abstract}
Introduction: The aim of the study is to find out the archives of smokers' readiness to quit smoking after the application of the Smoke-free House (RBAR) program.

Material and Methods: This type of research is a descriptive analytic study by using cross sectional approach. The research was conducted in a hamlet neighborhood (RW) that had been implementing RBAR program, and were selected randomly. They are RW 8 Tegal Panggung, RW 5 Tegal Panggung, RW 11 Ngupasan, RW 12 Bumijeo, RW 11 Gowongan. The samples were taken by cluster random sampling technique and obtained 70 heads of families with criteria of willing to be respondents, family heads (male), active smokers and permanent residents who lives in the study site since the RBAR program was first set in 2010. Data analysis was done by chi-square test.
\end{abstract}

Results: The result shows that attitudes has significant relation to the readiness of smokers to quit smoking after the application of the RBAR program ( $\mathrm{p}$ value $=0.030$ ).

Discussion and Conclusions: The carried out interventions can be adjusted to the stages of the smokers' behavior change process.

Keywords: readiness, attitude, quit smoking, stop smoking, smoker, smoke free house, implementation

\section{Introduction}

Smoking can murder up to half of consumers. Smoking murders nearly 6 millions people every year. More than 5 million of them are active smokers, while 600 thousand are passive smokers, this number exceeds the deaths caused by TBC, HIV/AIDS and malaria. Nearly $80 \%$ of the world's, 1 billion smokers live in low to middle income countries. About one person dies every 6 seconds because of smoking, accounting for 1 out of 10 deaths (World Health Organization, 2014).

Indonesia ranks the $3^{\text {rd }}$ largest number of smokers in the world after China and India (World Health Organization, 2014). In 2007, Indonesia was ranked as the $5^{\text {th }}$ largest cigarette consumer after China, the United States, Russia and Japan. In the same year, Basic Health Research stated that the population aged above 10 years who smoked was $29.2 \%$ and that number increased by $34.7 \%$ in 2010 for the age group above 15 years (Sjarif, 2011).

According to data (World Health Organization, 2011), Indonesia is one of the countries that has a higher smoking prevalence than the regional average and also higher than the world average. The increase in cigarette consumption has an impact to the higher burden of diseases caused by smoking and the rise of the death rate from smoking. In 2030 it is estimated that the death rate of smokers in the world will reach 10 millions and $70 \%$ of them come from developing countries.

The average number of cigarettes smoked per day for residents aged $\geq 10$ years in Indonesia is 12.3 cigarettes (equivalent to one pack). The highest proportion of active smokers on daily basis at the age of 30-34 years is 33.4 percent, men got higher rate than female smokers (47.5\% compared to $1.1 \%)$. Based on the type of work, farmers/fishermen/laborers are active smokers on daily basis who have the largest proportion (44.5\%) compared to other occupational groups. The proportion of population aged $\geq 15$ years who smoked and chewed tobacco tended to increase at Riskesdas (34.2\%), Riskesdas 2010 (34.7\%) and Riskesdas 2013 (36.3\%). Based on Global Adult Tobacco Survey (GATS) study, in the population of the age group $\geq 15$ years showed that the proportion of male 
smokers was 67.0 percent and in Riskesdas 2013 was 64.9 percent, while for women according to GATS, it was 2.7 percent and 2.1 percent according to the 2013 Riskesdas. The proportion of tobacco chewing according to GATS 2011 was 1.5 percent for men and 2.7 percent for women, while in the 2013 Riskesdas showed the proportion of men was 3.9 percent and 4.8 percent in women (Ministry of Health, 2014). The majority of cigarette factories develops their products without obeying the regulations set by the government such as not providing information to workers and consumers on the impact of the produced products (Etter, Zäther, \& Svensson, 2013).

Second-hand smoke is a major health hazard, especially for infants and children. Center for Disease Control and Prevention (CDC) reports that every year, six million deaths worldwide are caused by the use of tobacco products. The rise of tobacco consumption is also responsible for the higher exposure to SHS where more than 50 carcinogens and 4,000 potentially dangerous chemicals and toxins are present. These compounds are involved in lung cancer, heart disease and other diseases among nonsmokers (World Health Organization, 2011).

Women and children are victims of disproportionate Second-hand smoke. About $30 \%$ of men smoke, compared to $13 \%$ of women and $12 \%$ of teens aged $13-15$. It has been reported that as many as $40 \%$ of children and $35 \%$ of non-smoking women were affected by SHS in 2004. It is very likely that women and children, exposed to Second-hand smoke, have male family members who smoke at home or in personal vehicles. In low-income Southeast Asian countries, women are at least 50\% more likely to be victims of Second-hand smoke exposure than men. Children with smoking parents are also significantly more likely to be affected by Second-hand smoke (Practices, 2016).

Passive smokers cause more than 600,000 premature deaths per year. Everyone must be able to breathe tobacco-free air. Non-smokers' have smoke-free health laws, very popular, however it cannot be used to stop smoking. More than 1 billion people, or $16 \%$ of the world's population, are protected by a comprehensive smoke-free law (World Health Organization, 2014).

According to the CDC, for about 50,000 Americans die each year from lung and heart cancer due to exposure of other people's smoke (CDC, 2011). Other people's smoke (AROL) is indoor pollution which is very dangerous because more than $90 \%$ of people spend time indoors. According to Research (Pradono, Kesehatan, 2003), more than two-thirds of Indonesia's population has been exposed to cigarette smoke since birth, both men and women. The highest prevalence of passive smoker is in children under five and women of reproductive age 15-49 years. Overall the prevalence of passive smoking in all ages in Indonesia is $48.9 \%$. The prevalence of passive smoking in Yogyakarta especillay is between $53.4 \%-58.9 \%$. The number of women at risk for respiratory tract cancer is 4,859 .

Everyone has the right to get a high quality of health and free from tobacco-smoke environment. The Indonesian government has provided control of the cigarette issue, in the form of Government Regulation Number 109 of 2012 concerning Non-Smoking Areas (KTR). Non-Smoking Area (KTR) is a room or an which declared as prohibited area of smoking activities or activities in producing, selling, advertising, and/or promoting tobacco products. The arrangement of Non-Smoking Areas is a protection effort for the community against the risk of of health problems due to the polluted environment by cigarette smoke. The establishment of this Non-Smoking Area needs to be held in health care facilities, places of teaching and learning processes, places for children to play, places of worship, public transportation, workplaces, public places and other designated places (Ministry of Health, 2011).

KTR policies have developed in several regions. The results of the 2010 Riskesdas showed that Special Region of Yogyakarta (DIY) is one of the provinces with a high prevalence of smokers which, equal to $31.6 \%$, and as many as $66.1 \%$ still smoke inside the house. Active household smokers are more husbands or household heads than wives or children (DINAS KESEHATAN KOTA YOGYAKARTA, 2013). The Special Region of Yogyakarta has a policy governed by the Governor of DIY Regulation Number 42 of 2009 concerning Non-Smoking Areas. This policy aims to protect vulnerable groups (infants, toddlers, pregnant women and the elderly) and the public from the threat of health problems caused by the exposure of cigarette smoke (Gubernur Daerah Istimewa Yogyakarta, 2009). The DIY community itself has not fully complied with the Governor Regulation, because it is not widely known yet what kind type of regulation it is (Nugroho \& Istiyani, 2013).

In addition, the Mayor of the Special Region of Yogyakarta also gave a decision on Regional Regulation (Perda) Number 2 of 2017 concerning Non-Smoking Areas. The Non-Smoking Area, abbreviated as KTR, is a room or an area that allows smoking activities, selling and promoting tobacco products. The purpose of the regulations is to protect individuals health, families, communities and the environment from the risk of substances that can cause disease, death and degrade the quality of life (Pemerintah Kota Yogyakarta, 2017). 
In line with the establishment of the Non - Smoking Area (KTR) around the city of Yogyakarta, Quit Tobacco Indonesia (QTI) in collaboration with the Yogyakarta City Health Office initiated a smoke-free house program (RBAR) in the hamlet neighborhood of Yogyakarta City Center which is based in the Faculty of Medicine, Gadjah Mada University. This program focuses on protecting families from the dangers of cigarette smoke inside the house. The percentage of smoke-free households in DIY in 2012 only reached 44.6\% (Badan Penelitian dan Pengembangan Kesehatan Kementerian RI, 2010). This RBAR policy is very important, because this policy is one way to protect non-smokers from the dangers of cigarette smoke. One component is to eliminate smoking in the house (Quit Tobacco Indonesia, 2013).

The RBAR program was first conducted in four pilot areas in 2010, they are RW 11 Mujamuju, RW 1 Gunung Ketur, RW 6 Suryowijayan, and RW 4 Pakuncen (Indonesia Conference on Tobacco or Health, 2015). Till March 2018, the number of hamlet that have declared themselves as smoke free houses hamlet (RW) is increasing, it hits 137 Hamlets (Primary data, 2018).

The program related to RBAR policy making has been carried out by (SHAFA \& Murini, 2015) which is about the influence of RBAR on the smoking behavior of hamlet (RW) residents in Yogyakarta City. The results of the study showed that the number of mild smokers is decreasing from $32 \%$ to $6 \%$ as well as the number of heavy smokers from $34 \%$ to $6 \%$. In another study conducted by (Herry, 2017) about the relation between knowledge and attitudes to taxes on adolescents in RBAR, Yogyakarta City. The results of the study showed that $42.86 \%$ of respondents had a good level of knowledge and $6.67 \%$ of respondents had insufficient knowledge. There were $35.29 \%$ of respondents were positive and happy, while $5.88 \%$ were negative respondents. In multivariate analysis compared to knowledge, attitudes have greater disruption (Herry, 2017). The results of the two programs show that the RBAR program over a period of 5-7 years can reduce environmental behavior in the hamlet (RW) as well as youth neighborhood of RBAR Yogyakarta.

According to Velicher in (DINAS KESEHATAN KOTA YOGYAKARTA, 2013) mentioning the process of a person's behavior transformation from the pre-reflection stage to the stage of contemplation which starts from increasing health awareness, dramatic flow/experience or experiencing disease risk, and reevaluating the environment, and realizing the negative impact of health problems. Then the process of behavior changing from the contemplation stage to the stage of readiness, namely self-evaluation. The change of behavior and smoking attitudes in the study above shows the rise of community awareness and environmental evaluation in RBAR hamlet neighborhood, thus, in this $8^{\text {th }}$ year the community is already in the process of self-evaluation or being aware of behavioral changes to the stage of smoking cessation.

\section{Research Method}

This type of research is an analytical study with a cross sectional design. The study was conducted in hamlet neighborhoood which had implemented the RBAR program in Yogyakarta, they are Tegalpanggung RW 08, Tegalpanggung RW 05, Sorosutan RW 09, Bumijo RW 12 and Gowongan RW 11 starting from March until September 2018. The sample study was the head of the family which taken by cluster random sampling technique, with the following criteria: 1) willing to be a respondent, 2) family heads (male), 3) active smokers and 4) permanent residents who had stayed at the study site since the first time of the RBAR program was set in 2010 . Thus the minimum number of samples in this study was 70 respondents. Primary data was taken using a questionnaire to find out the identity of the respondents, the attitude and readiness of the respondent to stop smoking after applying the RBAR program. The independent variable in this study is attitude while the dependent variable is readiness to quit smoking.

The attitude applied in this study relates to the response of respondents in the form of acceptance or refusal to stop smoking. The categorization of attitudes is divided into two, namely positive and negative. It is categorized negatively if the score $<45.22$ and is positive if the score is $\geq 45.22$. This category is obtained from the calculation of the score which is the mean value of the respondents' total score. The attitude variable questionaire contains 20 statement items using a Likert scale

Smoking cessation readiness in this study relates to the stages that have been achieved by respondents in accordance with their goals and efforts to quit smoking. The categorization of smoking cessation readiness is divided into three, namely pre reflection, contemplation and preparation. Pre-contemplation is categorized if the respondent does not think of quitting smoking, contemplation is categorized if the respondent thinks he will stop smoking in the next 6 months, while preparation considered if the respondent thinks he will stop smoking in the next 30 days. Variable of smoking cessation readiness are 3 questions related to the effort of respondents to quit smoking after the implementation of smoke-free house program. The question form in the questionnaire is multiple choice and essay. 
Data analysis in this study carried out by using Chi square test (M Sopiyudin Dahlan, 2011) The analysis was conducted to determine the relationship between attitude and smoking cessation readiness in smokers who live in the RBAR hamlet neighborhood, Yogyakarta City.

Then the results of the study were analyzed using Chi Square test. Ethical clearance for this research was obtained from the research ethics committee of Ahmad Dahlan University, Indonesia (Letter of Ethical Approval, Number 011807107). Appropriate ethical conduct was maintained throughout the study.

\section{Results and Analysis}

\subsection{Results}

\subsubsection{Overview of Attitudes}

The results showed that respondents who had a positive attitude to quit smoking had a greater percentage, which was $52.9 \%$ compared to respondents who had a negative attitude $(47.1 \%)$. The description of the respondent's attitude based on the respondent characteristics is presented in Table 1 as follows:

Table 1. The overview of respondents' attitudes based on the characteristic $(n=70)$

\begin{tabular}{|c|c|c|}
\hline \multirow{2}{*}{ characteristic } & \multicolumn{2}{|l|}{ Sikap } \\
\hline & Negative n (\%) & Positive n (\%) \\
\hline \multicolumn{3}{|l|}{ Age } \\
\hline $17-25$ years old & $2(6,1 \%)$ & 0 \\
\hline 26-35 years old & $3(9,1 \%)$ & $6(6,2 \%)$ \\
\hline $36-45$ years old & $8(24,2 \%)$ & $11(29,7 \%)$ \\
\hline 46-55years old & $8(24,2 \%)$ & $16(43,2 \%)$ \\
\hline 56-65 years old & $10(30,3 \%)$ & $4(10,8 \%)$ \\
\hline$>65$ tahun & $2(6,1 \%)$ & 0 \\
\hline \multicolumn{3}{|l|}{ Latest education } \\
\hline Elementary -Junior High School & $16(48,5 \%)$ & $14(37,8 \%)$ \\
\hline Senior High School & $16(48,5 \%)$ & $17(45,9 \%)$ \\
\hline Diploma & 0 & $3(8,1 \%)$ \\
\hline Bachelor & $1(3 \%)$ & $3(8,1 \%)$ \\
\hline \multicolumn{3}{|l|}{ Job } \\
\hline Civil servants (PNS) & $1(3 \%)$ & $2(5,4 \%)$ \\
\hline Private employee & $10(30,3 \%)$ & $14(37,8 \%)$ \\
\hline Entrepreneur & $10(30,3 \%)$ & $7(18,9 \%)$ \\
\hline Labor & $12(36,4 \%)$ & $14(37,8 \%)$ \\
\hline \multicolumn{3}{|l|}{ Tingkat ketergantungan nikotin } \\
\hline Low & 0 & $1(2,7 \%)$ \\
\hline Average & $12(36,4 \%)$ & $12(32,4 \%)$ \\
\hline High & $21(63,6 \%)$ & $24(64,9 \%)$ \\
\hline Total & $33(100 \%)$ & $37(100 \%)$ \\
\hline
\end{tabular}

Source: Data Primer, 2018.

Based on Table 1, it can be seen that the largest percentage of respondents who have a positive attitude or support for quitting smoking are the respondents included in the age range of $46-55$ years which is $43.2 \%$ (16 respondents), respondents with a history of education completed by diploma is equal to $45.9 \%$ ( 17 respondents), respondents who had private employment and laborers were $37.8 \%$ (14 respondents) and the respondents with low levels of 
nicotine dependence were $64.9 \%$ ( 24 respondents).

\subsubsection{Overview of Readiness}

The description of respondent's readiness distribution is presented in Table 2, as follows:

Table 2. The distribution of respondents' readiness $(n=70)$

\begin{tabular}{lll}
\hline Readiness & Respondent number & Percentage (\%) \\
\hline Pre - reflection & 12 & $17,1 \%$ \\
Reflection & 22 & $31,4 \%$ \\
Preparation & 36 & $51,4 \%$ \\
\hline Total & $\mathbf{7 0}$ & $\mathbf{1 0 0 \%}$ \\
\hline
\end{tabular}

Source: Data Primer, 2018.

Based on Table 2, it can be seen that the results show the highest percentage of respondents is the respondents who are in the preparation stage for quitting smoking which is equal to $51.4 \%$ (36 respondents). This means that 36 respondents from the whole said they wanted to quit smoking in the next 30 days. The readiness portrayal based on the characteristics of the respondents is presented in Table 3 as follows:

Table 3. The overview of readiness based on the respondents' characteristics $(\mathrm{n}=70)$

\begin{tabular}{|c|c|c|c|}
\hline \multirow[b]{2}{*}{ Characteristics } & \multicolumn{3}{|l|}{ Readiness } \\
\hline & $\begin{array}{l}\text { Pre Reflection } \\
\text { n (\%) }\end{array}$ & $\begin{array}{l}\text { Reflection } \\
\text { n (\%) }\end{array}$ & $\begin{array}{l}\text { Readiness } \\
\text { n (\%) }\end{array}$ \\
\hline \multicolumn{4}{|l|}{ Age } \\
\hline $17-25$ years old & 0 & 0 & $2(5,6 \%)$ \\
\hline 26-35 years old & $1(8,3 \%)$ & $1(4,5 \%)$ & $7(19,4 \%)$ \\
\hline $36-45$ years old & $5(41,7 \%)$ & $10(45,5 \%)$ & $4(11,1 \%)$ \\
\hline $46-55$ years old & $4(33,3 \%)$ & $7(31,8 \%)$ & $13(36,1 \%)$ \\
\hline $56-65$ t years old & $1(8,3 \%)$ & $4(18,2 \%)$ & $9(25 \%)$ \\
\hline$>65$ years old & $1(8,3 \%)$ & 0 & $1(2,8 \%)$ \\
\hline \multicolumn{4}{|l|}{ Latest Education } \\
\hline Elementary -Junior High School & $3(25 \%)$ & $6(27,3 \%)$ & $21(58,3 \%)$ \\
\hline Senior High School & $9(75 \%)$ & $13(59,1 \%)$ & $11(30,6 \%)$ \\
\hline Diploma & 0 & $2(9,1 \%)$ & $1(2,8 \%)$ \\
\hline Bachelor & 0 & $1(4,5 \%)$ & $3(8,3 \%)$ \\
\hline \multicolumn{4}{|l|}{ Job } \\
\hline Civil servants (PNS) & $1(8,3 \%)$ & $1(4,5 \%)$ & $1(2,8 \%)$ \\
\hline Private employee & $4(33,3 \%)$ & $7(31,8 \%)$ & $13(36,1 \%)$ \\
\hline Entrepreneur & $3(25 \%)$ & $2(9,1 \%)$ & $12(33,3 \%)$ \\
\hline Labor & $4(33,3 \%)$ & $12(54,5 \%)$ & $10(27,8 \%)$ \\
\hline \multicolumn{4}{|l|}{ The rates of nicotin dependence } \\
\hline High & 0 & 0 & $1(2,8 \%)$ \\
\hline Average & $2(16,7 \%)$ & $9(40,9 \%)$ & $13(36,1 \%)$ \\
\hline Low & $10(83,3 \%)$ & $13(59,1 \%)$ & $22(61,1 \%)$ \\
\hline Total & $12(100 \%)$ & $22(100 \%)$ & $36(100 \%)$ \\
\hline
\end{tabular}

Source: Data Primer, 2018. 
Based on Table 3, it can be seen that the largest percentage of respondents who were in the pre-reflection stage or did not think about quitting smoking were the respondents in the age range of 36-45 years which was $41.7 \%$ ( 5 respondents), respondents with a history of completed education were $75 \%$ (9 respondents), respondents who have private jobs and entrepreneurs are 33.3\% (4 respondents). Respectively, respondents with low levels of nicotine dependence are $83.3 \%$ (10 respondents).

The largest percentage of respondents who are in the stage of contemplation or intending to quit smoking in the next 6 months is the respondents in the age range of 46-55 years of 31.8\% (7 respondents), respondents with high school education background were 59.1\% (13 respondents), and respondents with low levels of nicotine dependence were $59.1 \%$ (13 respondents).

While in the preparation stage or intending to quit smoking within the next 30 days the largest percentage of respondents were the respondents in the age range of 46-55 years which was $36.1 \%$ ( 13 respondents), respondents with a history of elementary-junior high school education were $58.3 \%$ (21 respondents), respondents who have private jobs amounted to $36.1 \%$ (13 respondents) and the respondents with low levels of nicotine dependence were $61.1 \%$ (22 respondents).

\subsubsection{The Relation of Attitude and Readinesss}

The researcher conducted a bivariate test for the smoking cessation attitude and readiness variables to find out the relationship between the two variables by using the Chi Square test. The results of the data show that the fulfillment of the Chi-Square test requirements is expected to be less than 5 by $0 \%$, then using the output at Pearson Chi-Square. The results of the Chi-Square test are presented in table 4 as follows:

Table 4. The relation of respondents' attitude to the smoking cessation readiness

\begin{tabular}{|c|c|c|c|c|c|c|c|c|c|}
\hline \multirow{3}{*}{ Attitude } & \multicolumn{6}{|c|}{ The Smoking Cessation Readiness } & \multirow{2}{*}{\multicolumn{2}{|c|}{ Total }} & \multirow{3}{*}{ Value $p$} \\
\hline & \multicolumn{2}{|c|}{ Pre Reflection } & \multicolumn{2}{|c|}{ Reflection } & \multicolumn{2}{|c|}{ Readiness } & & & \\
\hline & $\mathrm{n}$ & $\%$ & $\mathrm{n}$ & $\%$ & n & $\%$ & $\mathbf{n}$ & $\%$ & \\
\hline Negative & 11 & $33,3 \%$ & 8 & $24,2 \%$ & 14 & $42,4 \%$ & 33 & $100 \%$ & \\
\hline Positive & 1 & $2,7 \%$ & 14 & $37,8 \%$ & 22 & $59,5 \%$ & 37 & $100 \%$ & 0,003 \\
\hline
\end{tabular}

Source: Data Primer, 2018.

In Table 4, it can be seen that the number of respondents who have either negative or positive attitudes, hold the same highest percentage in the preparation stage, which are $42.4 \%$ and $59.5 \%$. The chi square test result value is 0.003 ( $\mathrm{p}$ value $<0.05$ ) so it can be concluded that there is a significant relationship between attitudes and smoking cessation readiness.

\subsection{Analysis}

\subsubsection{The Overview of Smoking Cessation Attitudes}

The results show that more than half of the respondents had a positive attitude to quit smoking, namely as many as 37 respondents (52.9\%). Most respondents agreed with the RBAR program and supported the program because it was often announced at community meetings about the rules in it. Factors that influence the formation of attitudes according to (Pradono et al., 2003) include personal experience, culture, others who are considered important, mass media, institutions, and individual emotions. Vulnerable time between the implementation of smoking bans and post-established rules is believed to be able to influence the increase in prevalence in the RBAR program (Mons et al., 2013, n.d.).

In this study, the characteristics of respondents who influence attitudes are the institutions or areas where the respondents live, who have implemented a smoke-free home program (RBAR). Based on the age characteristics, the highest number of respondents who have a positive attitude or support for quitting smoking is found in the group of respondents included in the age range of 46-55 years with a total of 16 respondents (43.2\%) compared to the group of respondents in other age ranges. One of the factors that influence attitudes is emotional factors, this is occured especially as attitude is the expressions of individual emotions where one's emotions are influenced by age (Pradono et al., 2003).

In the characteristics of the educational background that was completed, respondents with the most recent education history of elementary and junior high schools had a negative attitude percentage or did not support 
smoking cessation at most with a total of 16 respondents (48.5\%). In the low education group, they tend to be weak to stop smoking, even though there has been a short intervention in the group (Mons et al., n.d.). This shows that all respondents with the most recent education history in junior high schools have a negative attitude to stop smoking. Educational and religious institutions, greatly determine individual beliefs so that it will affect the individual's attitude towards an object (Pradono et al., 2003). This explains the educational degree taken by respondents have an influence on the attitude of respondents regarding smoke-free homes where respondents who have a history of low recent education will be more -likely to have a negative attitude.

In the characteristics of job, respondents who have the most negative attitudes compared to other occupational categories are 12 respondents $(36.4 \%)$ who work as laborers. Institutions or workplaces greatly determine individual trust so that it will affect the individual's attitude towards an object (Pradono et al., 2003). Research conducted (Ekpu \& Brown, 2015) shows that the prohibition on smoking in the workplace has long-term benefits besides affecting smoking behavior as well as saving health costs and increasing worker productivity. This explains the institution or work places of the respondent has an influence on the respondent's attitude regarding to the smoke-free homes where respondents who work as laborers tend to have negative attitudes.

In the characteristics of the nicotine dependency level category, the respondents with the highest percentage of positive attitudes or supporting smoking cessation were 24 respondents $(64.9 \%)$ with the lowest category of nicotine dependence. This explains the attitude factor are influenced by personal experience (Azwar Saifuddin, 2015). Respondents who had experienced smoking with the same level of nicotine dependence are tended to have a positive attitude to stop smoking.

\subsubsection{The Overview of Smoking Cessation Readiness}

The results show that the number of respondents who were in the pre-reflection stage or did not think of quitting smoking were 12 respondents (17.1\%). While respondents who are in the stage of contemplation or intend to quit smoking within the next 6 months are $22(31.4 \%)$. At the preparation stage or intending to quit smoking in the next 30 days as many as 36 respondents $(51.4 \%)$. The statistical results show that the data is not normally distributed with a value of sig 0,000 or less than 0.05 .

Based on psychological assessments of the level of readiness to quit smoking, Tiara Rismala Sari from Gadjah Mada University used questions listed by The University of Rhode Island and developed from the TTM by Prochaska. There are 3 questions, two questions that can assess the level of one's readiness to quit smoking and one supporting question (SARI \& Prabandari, 2016).

The first question is whether or not a smoker tried to stop smoking for at least 24 hours in the past year and the second question about whether or not there is a thought to stop smoking. Smokers who think of quitting smoking in the next 30 days with a history of never trying to quit smoking for at least 24 hours in the past year, he entered the stage of contemplation, while for smokers who have a history of trying to quit smoking for at least 24 hours in the past year, so he entered the preparation stage. Smokers think of quitting smoking in the next 6 months, entering the stage of contemplation. Smokers who do not think about quitting smoking at all enter the pre-contemplation stage.

Based on the explanation of the theory stated above, from this study it can be concluded that out of 70 respondents, $12(17.1 \%)$ were in the pre-reflection stage, $22(31.4 \%)$ were in the stage of reflection and $36(51.4 \%)$ in the preparation stage. Most respondents are in the preparation stage. This is because 14 out of 36 respondents who were in the preparation stage had a history of smoking-related illnesses so they decided to stop smoking within the next 30 days. This is supported by the theory of Transtheoretical Model according to Velicher in (DINAS KESEHATAN KOTA YOGYAKARTA, 2013) mentions the process of changing a person's behavior from the pre-reflection stage to the stage of contemplation which starts from increasing health awareness, dramatic flow/experience or risk of disease, and environmental reevaluation, realizing a negative impact from health problems. Then in the contemplation stage to the preparation stage a person experiences self-reevaluation or realizes that behavior change is an important part of one's identity as a person. Then someone will experience self-liberation or make a commitment to change. Because $35.7 \%$ of respondents experienced health problems due to smoking, they made behavioral changes to the stage of preparation or stopping smoking within the next 30 days.

Based on the age characteristics of respondents who are in the preparation stage or intending to quit smoking in the next 30 days , most of them belong to the group of respondents in the age range of $46-55$ years amounted to 13 respondents $(36.1 \%)$. This is influenced by the self-reevaluation factor where one realizes that behavior change is an important part of one's identity as a person (Australia, 2012).

In the characteristics of the completed educational backgoround most of them were respondents with a history of elementary-junior high school education, namely 21 respondents $(58.3 \%)$ who were in the preparation stage or 
intended to stop smoking within the next 30 days. This is because $21.4 \%$ of respondents with a history of elementary school and junior high school have experienced health problems due to smoking. This is part of a behavior change process which is where a person experiences a Dramatic Relief of negative emotions (fear, anxiety, worry) that are in line with the risk of certain behaviors (Australia, 2012).

In job characteristics, the respondents who were labor are mostly at the stage of contemplation or intend to stop smoking within the next 6 months, as many as 12 respondents (54.5\%). This is in line with the results above where the attitude of respondents who have labor jobs tends to be negative or not supportive of quitting smoking. According to (Wawan \& Dewi, 2010) negative attitudes lead to a tendency to stay away from, avoid, hate, dislike certain objects. Then respondents who have a negative attitude tend to choose the stage of contemplation to stop smoking

In the independent level category, the majority of respondents in the category of low nicotine dependence were 22 respondents $(61.1 \%)$ they were belong to the preparation stage or intended to quit within the next 30 days. According to (4) nicotine affects feelings, thoughts and functions at the cellular level. When someone sucks cigarette smoke, nicotine is extracted from tobacco, carried into the arterial circulation and reaches the brain. In this study, respondents had a low level of nicotine dependence, so it did not affect his mind to stop smoking too much.

\subsubsection{The Relation of Attitude and The Readiness to Quit Smoking}

The results show that respondents who had a positive attitude or supported to quit smoking and the respondents who had a negative attitude or did not support quitting smoking were at the same stage at the preparation stage with $59.5 \%$ ( 22 respondents) and $42.4 \%$ (14 respondents). This is supported by the results of statistical tests on the readiness data of respondents who are not normally distributed, thus it was resulted as above.

This is directly in line with Prochaska's Transtheoretical Model theory, which was developed by Velicher in (DINAS KESEHATAN KOTA YOGYAKARTA, 2013) in the contemplation stage to the preparation stage of someone experiencing self-reevaluation or realizing that behavior change is an important part of one's identity as a person. Then someone will experience self-liberation or make a commitment to change. A positive attitude is a form of self-reevaluation. The majority of respondents who have a positive attitude or support to stop smoking are in the preparation stage. In addition to the questionnaire question which points $35.7 \%$ ( 25 respondents) who have positive or negative attitudes claim to have experienced health problems due to smoking, this is what makes respondents who either have positive attitudes or negative attitudes or do not support quitting smoking dominate at the preparation stage or choose to stop smoking within the next 30 days.

As for other factors that influence smoking cessation readiness, that were not examined by researchers, were the length of smoking, knowledge of the hazards of smoking, advice on quitting smoking and health warnings on cigarette packs (Firzawati, 2015). In the study (Firzawati, 2015) said smokers who tried to quit smoking were smokers who had been smoking for less than 20 years, the longer smokers made their smoking habits would further reduce their chances of trying to quit smoking. Besides smoking behavior is related to knowledge and attitudes toward smoking, sufficient knowledge will motivate individuals to behave in a healthy manner. Firzawati also found that knowledge about the dangers of smoking is not wholly owned by smokers. Smokers who have knowledge of the dangers of smoking for their health will increase their desire to stop smoking (Firzawati, 2015). Research conducted (Layoun et al., n.d.) shows the intention to stop smoking in the first year, someone will try to reduce nicotine consumption, be negative about smoking and at a young age have a high awareness to regulate smoking cessation programs because they know the benefits of quitting smoking.

Based on the results of the study (Prayogi, Angraini, Majority, \& 2017, n.d.) doctor's advice is more effective and needs to be done in order to help active smokers stop smoking and protect passive smokers. Health warnings call can help smokers stop smoking or reduce the number of consumed cigarettes (Prayogi et al., n.d.). Media campaigns are effectively used to help as if the messages are delivered well to the differentiated groups to support them qutting smoking (Levy, Nikolayev, \& Mumford, 2005). According to the results of the study (Meko, 2016) the attitude of smokers who adequately support or apply warning images on cigarette packaging can make them have the motivation to stop smoking. Research conducted (Noar, Francis, Bridges, ..., \& 2016, n.d.) in countries such as Thailand, Canada, Mexico, and the United Kingdom shows that to provide benefits for people, avoiding lung cancer, heart disease, and other organ damage. Pictures for smoking on cigarette packs present damage to internal organs that can be used for health (Meko, 2016).

The results of this study indicate that the test result value is 0.003 . The p value is less than 0.05 so it can be concluded that there is a significant relationship between attitudes and smoking cessation readiness. This is 
supported by the Prochaska Transtheoretical Model theory which developed by Velicher in (DINAS KESEHATAN KOTA YOGYAKARTA, 2013) that the process of changing one's behavior is one of their awareness. Since the rise of awareness caused by the experience of a health problem can change a person's behavior to quit smoking even though his attitude is negative.

\section{Conclusion}

There is a significant relationship between attitude and readiness to quit smoking in the hamlet neighborhood (RW) of RBAR, Yogyakarta City. Thus, the results of this study can be used as material for evaluating the achievement of smoke-free home programs. It is better for the Yogyakarta City government to provide regular education about the purpose of a smoke-free home program so that smokers are aware and better understand the purpose of a smoke-free home program. For the development of further research, more in-depth research can be conducted on other factors that influence smoking cessation readiness, those are smoking time, knowledge of the dangers of smoking, smoking cessation advice and health warnings on cigarette packs. In addition, it can also be a more detailed research in the stage of quitting smoking so that it can be known not only in the stage of pre-reflection, contemplation and preparation but also other stages.

\section{Competing Interests Statement}

The authors declare that there are no competing or potential conflicts of interest.

\section{References}

Australia, B. W. (2012). Stage theories and behaviour change. Retrieved from $\mathrm{http} / /$ www.behaviourworksaustralia.org/V2/wp-content/uploads/2015/02/BWA_StageTheories.pdf

Azwar Saifuddin. (2015). Sikap Manusia Teori dan Pengukurannya (2nd ed.). Yogyakarta: Pustska Pelajar.

Badan Penelitian dan Pengembangan Kesehatan Kementerian RI. (2010). Riset Kesehatan Dasar. Jakarta.

CDC. (2011). Decrease in Smoking Prevalence. Jurnal Morbidity and Mortality Weekly Report.

DINAS KESEHATAN KOTA YOGYAKARTA. (2013). Profil Kesehatan Kota Yogyakarta. Yogyakarta. Retrieved from http://www.pusdatin.kemkes.go.id/resources/download/profil/PROFIL_KAB_KOTA_2012/3471_DIY_Kot a_Yogyakarta_2012.pdf

Ekpu, V. U., \& Brown, A. K. (2015). The Economic Impact of Smoking and of Reducing Smoking Prevalence: Review of Evidence. Tobacco Use Insights, 8, TUI.S15628. https://doi.org/10.4137/TUI.S15628

Etter, J.-F., Zäther, E., \& Svensson, S. (2013). Analysis of refill liquids for electronic cigarettes. Addiction, 108(9), 1671-1679. https://doi.org/10.1111/add.12235

Firzawati. (2015). Universitas Indonesia Faktor Upaya Berhenti Merokok Pada Perokok Aktif Umur 15 Tahun Keatas Di Indonesia Disertasi Firzawati 0806475486 Fakultas Ilmu Kesehatan Masyarakat Program Studi Doktor Depok June 2015. Retrieved from http:/lib.ui.ac.id/file?file=digital/2016-4/20416068-D2086Firzawati.pdf

Gubernur Daerah Istimewa Yogyakarta. Peraturan Gubernur Daerah Istimewa Yogyakarta (2009). Yogyakarta Indonesia. Retrieved from http://bdiyogyakarta.kemenperin.go.id/dip/3. Informasi Serta Merta/2. Yogyakarta_Peraturan-Gubernur-No.-42-Thn-2009-ttg-KDM.pdf

Herry, R. F. (2017). Hubungan Pengetahuan dan Sikap tentang Rokok Pada Remaja Terhadap Kepatuhan Aturan Merokok di Rumah Bebas Asap Rokok Kota Yogyakarta. Gadjah Mada Yogyakarta.

Indonesia Conference on Tobacco or Health. (2015). 2nd Indonesia Conference on Tobacco or Health. In Tobacco Control: Saves Young Generation, Saves the Nation. Jakarta Indonesia. Retrieved from http://www.ictoh.tcsc-indonesia.org

Layoun, N., Hallit, S., Waked, M., Bacha, Z. A., Godin, I., Leveque, A., ... \& Salameh, P. (2017). Predictors of past quit attempts and duration of abstinence among cigarette smokers. Journal of epidemiology and global health, 7(3), 199-206.

Levy, D. T., Nikolayev, L., \& Mumford, E. (2005). Recent trends in smoking and the role of public policies: results from the SimSmoke tobacco control policy simulation model. Addiction, 100(10), 1526-1536. https://doi.org/10.1111/j.1360-0443.2005.01205.x

Sopiyudin, D. M. (2011). Statistik untuk kedokteran dan kesehatan (3rd, ed.). Jakarta: Salemba Jakarta. Retrieved from https://books.google.co.id/books?hl=en\&lr=\&id=Abh5OaO3qlMC\&oi=fnd\&pg=PA1\&dq=sofiudin 
+ dahlan\&ots=SVUBPe14zV\&sig=owC4r1r9jphn9ZKR3vNW6HwDVEQ\&redir_esc=y\#v=onepage\&q=sof iudin dahlan\& $\mathrm{f}=\mathrm{false}$

Meko, A. (2016). Hubungan antara Sikap terhadap Gambar Peringatan Bahaya Merokok pada Kemasan Rokok dengan Motivasi Berhenti Merokok. Retrieved from http://repository.uksw.edu/handle/123456789/10177

Ministry of Health. (2011). Riset Kesehatan Dasar. Jakarta: Kementerian Kesehatan Indonesia.

Ministry of Health. (2014). Petunjuk Teknis Upaya Berhenti Merokok pada Fasilitas Pelayanan Kesehatan Primer (Ke-2nd ed., pp. 17-34). Jakarta Indonesia.

Mons, U., Nagelhout, G., ... S. A.-T., \& 2013, undefined. (n.d.). Impact of national smoke-free legislation on home smoking bans: findings from the International Tobacco Control Policy Evaluation Project Europe Surveys. Tobaccocontrol.bmj.com. Retrieved from https://tobaccocontrol.bmj.com/content/22/e1/e2.short

Noar, S. M., Francis, D. B., Bridges, C., Sontag, J. M., Ribisl, K. M., \& Brewer, N. T. (2016). The impact of strengthening cigarette pack warnings: Systematic review of longitudinal observational studies. Social Science \& Medicine, 164, 118-129. Retrieved from https://www.sciencedirect.com/science/article/pii/S0277953616302921

Nugroho, D.J, Istiyani, T. (2013). Tingkat Pengetahuan dan Kepatuhan Masyarakat DIY Terhadap Peraturan Gubernur Nomor 42 Tahun 2009 tentang Pengamanan Rokok bagi Kesehatan. Yogyakarta.

Pemerintah Kota Yogyakarta. (2017). Peraturan daerah kota yogyakarta nomor 2 tahun 2017 kawasan tanpa rokok. Retrieved from https://hukum.jogjakota.go.id/data/Perda No 2 Tahun 2017 ttg Kawasan Tanpa Rokok.pdf

Practices, C. for the S. of I. M. P. and. (2016). Health Effect of Tobacco Seconhand Smoke: Focus on Children Health A Review of The Evidence and Self-Assessment. USA.

Pradono, J., \& Kristanti, C. M. (2012). Perokok pasif bencana yang terlupakan. Buletin penelitian kesehatan, 31 (4 Des). Retrieved from http://ejournal.litbang.kemkes.go.id/index.php/BPK/article/viewFile/2070/1182

Prayogi, B., Angraini, D., Majority, E. C.-J., \& 2017, undefined. (n.d.). Peran Dokter terhadap MPOWER sebagai Upaya Berhenti Merokok di Layanan Kesehatan Primer. Juke.kedokteran.unila.ac.id. Retrieved from http:/juke.kedokteran.unila.ac.id/index.php/majority/article/view/1759

Quit Tobacco Indonesia. (2013). Panduan Rumah Bebas Asap Rokok. Yogyakarta: Fakultas Kedokteran UGM.

Sari, T., \& Prabandari, Y. (2016). Sikap dan Kesiapan untuk Berhenti Merokok menurut Transtheoretical Model setelah Penerapan Kebijakan Kawasan Tanpa Rokok pada Karyawan PT. Kaltim Prima. Retrieved from http://etd.repository.ugm.ac.id/index.php?mod=book_detail\&sub=BookDetail\&act=view\&typ=htmlext\&bu ku_id $=93985 \&$ obyek_id $=4 \&$ unitid $=\& j e n i s \_i d=$

Shafa, N., \& Murini, T. (2015). Pengaruh kebijakan rumah bebas asap rokok terhadap perilaku merokok warga di dusun kemloko, desa srimartani, bantul. Retrieved from http://etd.repository.ugm.ac.id/index.php?act=view\&buku_id=80126\&mod=penelitian_detail\&sub=Peneliti anDetail\&typ $=\mathrm{html}$

Sjarif, D. (2011). Riset Kesehatan Dasar. Badan Penelitian dan Pengembangan Kesehatan Kementerian RI.

Wawan, \& Dewi. (2010). Teori dan Pengukuran Pengetahuan. Yogyakarta: Nuha Medika.

World Health Organization [WHO]. (2011). Gats indonesia global adult tobacco survey: indonesia report 2011 collaborating organizations. Jakarta Indonesia. Retrieved from http://apps.who.int/iris/bitstream/handle/10665/205137/B4934.pdf?sequence=1\&isAllowed=y

World Health Organization [WHO]. (2014). Global Adult Tobacco Survey: Indonesia Report. Jakarta.

\section{Copyrights}

Copyright for this article is retained by the author(s), with first publication rights granted to the journal.

This is an open-access article distributed under the terms and conditions of the Creative Commons Attribution license (http://creativecommons.org/licenses/by/4.0/). 